\title{
DAYA SAING BANK SYARIAH DI SEBUAH NEGARA RELIGIUS: TEMUAN EMPIRIK DARI INDONESIA
}

\author{
Tastaftiyan Risfandy, Putri Permatasari Husa, Andi Asrihapsari \\ Fakultas Ekonomi dan Bisnis Universitas Sebelas Maret \\ JI. Ir Sutami 36 A Surakarta 57126, Indonesia
}

\begin{abstract}
This is the first study examining the market power of Islamic banks in Indonesia which using quarterly data. Specifically, this paper attempts to answer a question whether, in the high-religiosity country as Indonesia, Islamic banks have greatermarket power compared to its conventional counterparts. We construct Lerner's index to measure banks market power by using data from 2009 to 2013. We found that even in a biggest Muslim country in the world, Islamic banks have lowest market power. The result suggests that central banks of Indonesia should consider an alternative methods to promote Islamic banks market power since the balance between those two types of banks may enhance country financial stability.
\end{abstract}

Keywords: market power, Lerner index, Islamic banks, Indonesia

\section{PENDAHULUAN}

Perkembangan bank syariah di dunia saat ini telah menarik perhatian banyak kalangan, diantaranya adalah para praktisi dan akademisi. Berpusat di wilayah Timur Tengah, Afrika Utara, dan Negara-negara Muslim lainnya, bank syariah tumbuh sebesar $15 \%$ - $50 \%$ per tahun lebih tinggi dari bank konvensional (Ernst \& Young, 2014). Dengan jumlah sekitar 38 juta nasabah di seluruh dunia, total asset dari industri perbankan syariah di seluruh dunia telah mencapai US\$ 1,7 milyar di tahun 2013. Meskipun pangsa pasar bank syariah di dunia masih kurang dari $2 \%$ (Beck et al., 2013), dengan kinerjanya yang positif dan per- tumbuhannya yang menjanjikan dapat menjadi indikasi kemampuan bank syariah untuk dapat bersaing dengan bank konvensional di industri perbankan dunia, terutama di negara-negara yang mayoritas penduduknya adalah Muslim.

Dalam rangka menyoroti perkembangan perbankan syariah, artikel ini akan menelaah lebih lanjut mengenai daya saing (market power) atau tingkat kompetitif (competitiveness) bank syariah. Weill (2011) mendefinisikan daya saing sebagai kemampuan perbankan dalam mempengaruhi harga produk dan jasa perbankan yang dibebankan kepada nasabah. Daya saing bank syariah dapat dikaitkan dengan kompetisi di dalam industri perbankan. Semakin tinggi daya saing bank secara rata-rata

Korespondensi dengan Penulis:

Tastaftiyan Risfandy: Telp +6285647384984, (0271) 646994, Faks. (0271) 646655

Email: tastaftiyan.risfandy@staff.uns.ac.id 


\section{Daya Saing bank Syariah di Sebuah Negara Religius: Temuan Empirik dari Indonesia}

Tastaftiyan Risfandy, Putri Permatasari Husa, Andi Asrihapsari

mengindikasikan rendahnya tingkat kompetisi pada pasar perbankan tersebut (Fu et al., 2014; Love \& Martinez-Peria, 2015). Secara khusus, penelitian ini ditujukan untuk menjawab pertanyaan, apakah daya saing bank syariah secara signifikan lebih tinggi atau lebih rendah dibandingkan dengan bank konvensional.

Penelitian ini sangat penting untuk dilakukan setidaknya karena dua hal. Pertama, hasil dari penelitan sebelumnya tidak menghasilkan kesimpulan tentang apakah bank syariah memiliki daya saing yang lebih baik atau sebaliknya. Turk-Ariss (2010) menemukan bahwa bank syariah memiliki daya saing yang rendah, sementara Hamza dan Katchouli (2014) menemukan bahwa bank yang menerapkan hukum ekonomi syariah justru memiliki tingkat kompetisi yang lebih baik daripada bank konvensional. Di sisi yang lain, Weill (2011) mengamati bahwa kedua tipe perbankan tidak memiliki perbedaan yang signifikan dalam hal daya saingnya. Kedua, meskipun bank konvensional memiliki beberapa keunggulan seperti penggunaan teknologi yang mutakhir, tenaga kerja yang handal dan telah memiliki posisi di industri perbankan, hal tersebut tidak menjadi jaminan bahwa bank konvensional memiliki daya saing yang lebih baik dan kuat. Sejak kemunculan dan perkembangan bank syariah di negara-negara Muslim, timbullah suatu penilaian bahwa seharusnya bank syariah lebih banyak mendapatkan tempat di hati populasi Muslim. Nasabah yang memiliki tingkat religiusitas yang tinggi akan tetap memilih bank syariah meskipun return yang didapatkan akan lebih rendah. Mereka dapat memilih akan menempatkan dananya di bank syariah manapun yang dikehendakinya karena banyak sekali pilihan bank syariah dalam industri perbankan saat ini.

Penelitian ini menggunakan Indeks Lerner untuk menganalisis daya saing bank syariah di Indonesia dari tahun 2009 sampai 2013. Indeks Lerner cukup sering digunakan dalam riset-riset perbankan (sebagai contoh, Weill (2011), Leon
(2015), Love \& Martinez-Peria (2015), Tan (2015), dan masih banyak lagi) salah satunya karena indeks Lerner dapat mengukur daya saing perbankan secara endogenus (Soedarmono et al., 2011). Indeks Lerner mengukur "seberapa mampukah" sebuah bank atau industri perbankan menentukan harga produk dan jasa perbankan yang dikenakan kepada nasabah di atas biaya marginal yang harus dikeluarkan bank. Semakin tinggi harga produk dan jasa perbankan diatas biaya marginal menunjukkan semakin tinggi daya saing bank tersebut.

Indeks Lerner dihitung di setiap bank dan di setiap tahun dengan menggunakan metode dari Weill (2011) dan Turk-Ariss (2010). Untuk menentukan apakah bank syariah dan bank konvensional memiliki daya saing yang berbeda, penelitian ini menggunakan uji beda rata-rata. Penelitian ini juga akan menginvestigasi perbedaan daya saing kedua tipe bank dengan analisis Pooled Least Square (PLS).

Sepengetahuan peneliti, belum ada penelitian yang menguji daya saing bank syariah di Indonesia. Peneliti fokus pada Indonesia karena selain sebagai negara dengan penduduk Muslim terbesar di dunia, Indonesia adalah satu dari sekian banyak negara Muslim yang memiliki tingkat religiusitas yang tinggi, dengan skor religiusitas yang mencapai 99\% (World Bank, 2014). Dengan demikian, penelitian ini akan memberikan kontribusi signifikan pada literatur empirik bank syariah khususnya di Indonesia. Output dari hasil penelitian ini juga dapat digunakan oleh para pembuat kebijakan, baik bagi mereka yang duduk di posisi manajemen maupun mereka yang duduk di pemerintahan. Bank Indonesia harus mempertimbangkan metode alternatif dalam menggenjot daya saing bank syariah karena keseimbangan kedua tipe bank tersebut dapat meningkatkan stabilitas keuangan. Bagi para manajer bank khususnya bank syariah, penelitian ini dapat menjelaskan tentang tingkat daya saing bank yang sedang mereka kelola. 


\section{TINJAUAN LITERATUR}

\section{Perbankan Syariah di Indonesia}

Di Indonesia, bank syariah dipandang oleh Bank Indonesia sebagai alternatif sistem perbankan untuk masyarakat yang Indonesia yang beragam. Bank Indonesia mengharapkan Bank syariah dan bank konvensional untuk saling melengkapi dalam mobilisasi dana masyarakat ke dunia perbankan. Senada dengan Gheeraert (2014), a pabila bank syariah dapat menjangkau masyarakat yang tidak mau menggunakan jasa perbankan konvensional, total dana perbankan yang dihimpun dari masyarakat yang akan digunakan untuk menggenjot roda perekonomian akan semakin tinggi. Bank syariah juga memiliki banyak alternatif pembiayaan kepada nasabah yang religius, seperti qardhul hasan (Falikhatun et al., 2016), yang dapat menjadi motor penghimpunan dana masyarakat.

Dalam rangka menunjang perkembangan bank yang berbasis religiusitas ini, Bank Indonesia telah membentuk Direktorat Perbankan Syariah di tahun 2001. Tujuan dari dibentuknya entitas ini adalah untuk melakukan proses sosialisasi dan edukasi kepada masyarakat agar lebih banyak terlibat dalam aktivitas perbankan khususnya dengan bank syariah. Sebagaimana telah dijelaskan dalam Demirgüç-Kunt et al. (2013), sekolompok orang dengan tingkat religiusitas yang cukup tinggi menolak untuk melibatkan perbankan dalam kegiatan perekonomian mereka dengan alasan perbankan dilarang dalam agama Islam. Dengan keberadaan Direktorat Perbankan Syariah, pandangan tersebut diharapkan tidak akan ada lagi.

Peraturan baru mengenai perbankan syariah telah diluncurkan di Indonesia pada pertengahan tahun 2008 (Undang-Undang no. 21 Tahun 2008). Bank syariah di Indonesia diharapkan dapat tumbuh lebih cepat lagi setelah peraturan ini diberlakukan, karena sebelum adanya peraturan ini bank syariah beroperasi tanpa landasan hukum yang jelas. Dengan adanya peraturan baru ini dan hadir- nya Direktorat Perbankan Syariah, bank syariah di Indonesia diharapkan dapat berkontribusi dalam peningkatan stabilitas keuangan negara bersama dengan bank konvensional.

\section{Indeks Lerner dan alat ukur kompetisi pasar lainnya}

Sebelum adanya indeks Lerner yang saat ini banyak digunakan dalam penelitian perbankan untuk mengukur daya saing bank, akademisi dan peneliti di area perbankan menggunakan konsentrasi pasar atau Herfindahl-Hirschman Index (HHI). Konsentrasi pasar biasanya diukur dengan menggunakan total asset dari tiga atau lima bank terbesar di pasar. Jika tiga atau lima sampel tersebut total asetnya berjumlah lebih dari $50 \%$ dari total asset industri perbankan, maka bisa dikatakan bahwa pasar perbankan tersebut terkonsentrasi dan memiliki tingkat kompetisi yang rendah. HHI dihitung dengan menjumlahkan kuadrat dari market share semua bank di pasar (industri). Nilai dari indeks ini adalah antara 0 sampai 1 . Semakin tinggi nilai indeks menggambarkan pasar yang semakin terkonsentrasi dan tingkat kompetisi yang semakin rendah.

Baik konsentrasi pasar maupun HHI digunakan untuk mengukur tingkat daya saing secara tidak langsung melalui nominal aset bank. Kedua proksi tersebut tidak dapat mengukur daya saing masing-masing bank secara langsung. Dalam hal ini, indeks Lerner lebih relevan karena dapat mengukur daya saing masing-masing bank secara individual. Indeks ini merupakan alat ukur langsung untuk kompetisi pasar karena indeks tersebut fokus pada kemampuan bank untuk menentukan harga produk atau jasa bagi nasabah bank (Weill, 2011). Secara sederhana, Indeks Lerner menjelaskan selisih dari harga produk yang dibebankan kepada konsumen dan biaya marginal yang dikeluarkan oleh bank. Semakin tinggi harga dari produk di atas biaya marginalnya, semakin tinggi 
indeks Lerner yang dihasilkan dan hal tersebut mengindikasikan semakin tingginya daya saing bank.

Beberapa peneliti seperti Turk-Ariss (2010), Hamza \& Katchouli (2014), dan Mulyaningsih et al., (2015) menggunakan $H$-Statistics dari metode Panzar-Rosse untuk menghitung daya saing sebagai robustness check dari indeks Lerner. Proksi ini juga cukup banyak digunakan dalam penelitian di bidang perbankan, terutama untuk menilai kompetisi di tingkat pasar (industri). Namun penelitian ini hanya fokus pada indeks Lerner karena penelitian ini tidak bertujuan untuk mengukur tingkat kompetisi pasar. Penelitian ini hanya bertujuan untuk mengukur tingkat daya saing untuk setiap bank secara individual, dimana hal ini tidak dapat dilakukan jika menggunakan metode model PanzarRosse.

\section{METODOLOGI}

\section{Data}

Peneliti menggunakan laporan keuangan kuartal dari tahun 2009 sampai dengan 2011 yang bersumber dari Bank Indonesia. Peneliti tidak menggunakan laporan keuangan tahunan untuk menghidari tidak cukupnya observasi untuk bank syariah. Walaupun bank syariah pertama di Indonesia telah ada sejak 1992, bank syariah yang lain baru muncul setelah Undang-Undang Perbankan syariah dibuat pada tahun 2008. Peneliti menggunakan lima besar bank syariah dan bank konvensional seperti yang ditampilkan pada tabel 1 .
Kesepuluh bank tersebut telah mewakili $80 \%$ pangsa pasar perbankan di Indonesia.

\section{Indeks Lerner}

Metode penghitungan indeks Lerner dalam penelitian ini sesuai dengan Weill (2011) dan TurkAriss (2010). Langkah pertama dalam menghitung indeks Lerner adalah mengestimasi $\alpha$ dan $\gamma$ menggunakan fungsi biaya trans-logaritma seperti yang ada dalam persamaan (I) sebagai berikut.

$$
\begin{aligned}
& \ln (\mathrm{TC})=\propto_{0}+\propto_{1} \ln (\mathrm{TA})+\frac{1}{2} \propto_{2}(\ln \mathrm{TA})^{2}+\sum_{\mathrm{j}=1}^{3} \beta_{\mathrm{j}} \ln \left(\mathrm{W}_{\mathrm{j}}\right) \\
& \quad+\sum_{\mathrm{j}=1}^{3} \sum_{\mathrm{k}=1}^{3} \beta_{\mathrm{jk}} \ln \left(\mathrm{W}_{\mathrm{j}}\right) \ln \left(\mathrm{W}_{\mathrm{k}}\right)+\sum_{\mathrm{j}=1}^{3} \gamma_{\mathrm{j}} \ln (\mathrm{TA}) \ln \left(\mathrm{W}_{\mathrm{j}}\right)+\varepsilon \\
& \mathrm{MC}=\frac{\mathrm{TC}}{\mathrm{TA}}\left(\propto_{1}+\propto_{2} \ln (\mathrm{TA})+\sum_{\mathrm{j}=1}^{3} \gamma_{\mathrm{j}} \ln \left(\mathrm{W}_{\mathrm{j}}\right)\right) \\
& \text { Lerner }_{\mathrm{it}}=\frac{\text { Price }_{\mathrm{it}}-\mathrm{MC}_{\mathrm{it}}}{\text { Price }_{\mathrm{it}}}
\end{aligned}
$$

Dimana TC adalah total biaya, TA adalah total aset, dan $W_{j}$ mengacu pada tiga input biaya yang dikeluarkan oleh bank sebagai komponen dari biaya marginal. $W_{j}$ dapat diklasifikasikan sebagai $\mathrm{W}_{1}$ (biaya tenaga kerja), $\mathrm{W}_{2}$ (biaya modal) dan $\mathrm{W}_{3}$ (biaya pendanaan). Biaya tenaga kerja adalah rasio biaya tenaga kerja terhadap total aset. Biaya modal dikalkulasi dengan membagi beban non-bunga terhadap aset tetap. Terakhir, biaya pendanaan adalah rasio beban bunga terhadap total pendanaan yang dilakukan perusahaan.

\begin{tabular}{|c|c|}
\hline Bank Syariah & Bank Konvensional \\
\hline 1. Bank Muamalat Indonesia (BMI) & 1. Bank Mandiri (Mandiri) \\
\hline 2. Bank Syariah Mandiri (BSM) & 2. Bank BRI (BRI) \\
\hline 3. Bank Mega Syariah (BMS) & 3. Bank BCA (BCA) \\
\hline 4. $\quad$ Bank BRI Syariah (BRIS) & 4. Bank BNI (BNI) \\
\hline 5. Bank Syariah Bukopin (BSB) & 5. Bank CIMB-Niaga (CIMBNiaga) \\
\hline
\end{tabular}

Persamaan (I) diestimasi menggunakan pooled least squares dengan opsi robust cluster untuk mengo-

Tabel 1. Sampel 
reksi standar eror. Opsi ini dilakukan untuk menghindari problem heteroskedastisitas pada regresi. Karena daya saing bank dari tahun ke tahun dimungkinkan untuk berbeda, persamaan (I) diestimasi tahun per tahun (2009-2013) untuk setiap pasar perbankan (syariah dan konvensional) atau 5 kali regresi dengan $5 \alpha$ dan $\gamma$.

Koefisien yang didapat dari regresi translogaritma tersebut kemudian digunakan untuk menghitung biaya marginal bank seperti pada persamaan (II). Langkah terakhir dalam penghitungan indeks Lerner adalah menjalankan persamaan (III), yaitu mengurangkan harga produk perbankan (Price) dengan biaya marginal (MC) yang didapat dari persamaan (II). Harga produk perbankan itu sendiri adalah total pendapatan (jumlah dari pendapatan bunga dan pendapatan non-bunga) dibagi dengan total aset.

Indeks Lerner secara umum berkisar diantara angka 0 dan 1 . Semakin tinggi indeks Lerner mengindikasikan daya saing bank yang semakin tinggi. Sebagai contoh, sebuah bank dengan indeks Lerner 0,8 dapat diartikan bahwa bank tersebut memiliki kemampuan untuk menetapkan harga produk perbankan mereka $80 \%$ diatas biaya marginal yang mereka keluarkan. Akan tetapi, Soedarmono et al. (2011) berpendapat bahwa indeks Lerner dapat bernilai negatif. Hal ini dapat terjadi pada bank yang tidak bekerja secara optimal, yaitu saat harga produk dan jasa mereka lebih rendah dari biaya marginal yang mereka keluarkan.

\section{Beda daya saing bank syariah dan bank konvensional}

Peneliti melakukan uji beda rata-rata untuk menjawab pertanyaan apakah terdapat perbedaan yang signifikan antara daya saing bank syariah dan bank konvensional. Peneliti juga akan melakukan analisis pooled least square (PLS) dengan menggunakan opsi koreksi standar eror. Analisis ini juga memasukkan tiga variabel kontrol yang dihipotesis- kan memiliki pengaruh pada daya saing bank. Uji ini dirumuskan dalam persamaan (IV) sebagai berikut:

$$
\begin{aligned}
\text { Daya }_{\text {Saing }} \text { it } & =\alpha+\beta_{1} \text { Syariah }_{\mathrm{i}}+\text { Utilisasi }_{\text {Aset }} \text { it } \\
& +\beta_{3} \text { Risiko }_{\text {it }}+\beta_{4} \text { Kuartal }_{\mathrm{t}}+\varepsilon_{\text {it }}
\end{aligned}
$$

Persamaan IV tersebut menggunakan tiga variabel kontrol. Variabel pertama adalah rasio kredit terhadap total aset (Utilisasi_Aset ${ }_{i t}$ ) yang digunakan untuk mengukur perbedaan utilisaasi aset di tiap bank. Variabel kedua adalah risiko bank $\left(\right.$ Risiko $\left._{i t}\right)$ yang dihitung dengan rasio total ekuitas terhadap total aset bank. Ketiga, peneliti menggunakan variabel dummy kuartal (Kuartal) untuk menangkap perbedaan perilaku bank di tiap kuartal. Ketiga variabel tersebut konsisten dengan De Guevara et al. (2005). Daya_saing ${ }_{i t}$ adalah indeks Lerner bank yang sebelumnya telah dihitung. Syariah ${ }_{i}$ adalah variabel dummy yang menunjukkan jenis bank, yang memiliki nilai 1 jika bank syariah dan 0 jika bank konvensional.

\section{HASIL DAN PEMBAHASAN}

\section{Statistik deskriptif}

Statistik deskriptif penelitian ini tersaji dalam Tabel 2. Dapat disimpulkan bahwa terdapat perbedaan yang cukup mencolok antara bank syariah dan konvensional di Indonesia dalam hal total aset, kredit (pembiayaan), dan ekuitas. Sebagai contoh, Bank Muamalat Indonesia (BMI) sebagai bank syariah yang memberikan pembiayaan tertinggi (Rp 21,2 milyar) dibanding bank syariah yang lain masih tertinggal jauh jika dibandingkan Bank Mandiri (Rp 417 milyar). Sebagai bank syariah terbesar dari sisi total asetnya, Bank Syariah Mandiri (BSM) hanya $10 \%$ dibandingkan dengan former parent Bank Mandiri. Secara umum, berdasarkan data yang dimiliki peneliti, total aset lima bank syariah di Indonesia hanya 6,4\% dari total aset perbankan di Indonesia. 
Utilisasi asset bank konvensional juga lebih baik dari bank syariah. Bank konvensional secara rata-rata mengalokasikan $66 \%$ dari aset mereka untuk kredit atau pembiayaan, sedangkan bank syariah hanya $21 \%$ saja. Bank konvensional juga memperlihatkan solvabilitas yang lebih baik (risiko lebih rendah), yang ditunjukkan dari rasio ekuitas terhadap total aset. Rasio kapital bank konven-

Tabel 2. Statistik deskriptif (Kuartal IV tahun 2013)

\begin{tabular}{|c|c|c|c|c|c|c|c|}
\hline No & Bank & Tipe & $\begin{array}{l}\text { Total Asset } \\
\text { (TA) }\end{array}$ & Kredit & Ekuitas & $\begin{array}{c}\text { Kredit } \\
\text { /TA }\end{array}$ & $\begin{array}{c}\text { Ekuitas } \\
\text { /TA }\end{array}$ \\
\hline 1 & BMI & Syariah & 54.700 .000 & 21.200 .000 & 4.291 .094 & 0,388 & 0,078 \\
\hline 2 & BSM & Syariah & 64.000 .000 & 11.100 .000 & 4.861 .999 & 0,174 & 0,076 \\
\hline 3 & BMS & Syariah & 9.121 .575 & 43.593 & 770.053 & 0,005 & 0,084 \\
\hline 4 & BRIS & Syariah & 17.400 .000 & 4.050 .478 & 1.698 .128 & 0,233 & 0,098 \\
\hline 5 & BSB & Syariah & 4.343 .069 & 1.092 .737 & 292.620 & 0,252 & 0,067 \\
\hline \multicolumn{3}{|c|}{ Total \& Rata-rata } & 149.564 .644 & 37.486 .808 & 11.913 .894 & 0.210 & 0,081 \\
\hline 6 & Mandiri & Konven. & 648.000 .000 & 417.000 .000 & 82.600 .000 & 0,643 & 0,127 \\
\hline 7 & BRI & Konven. & 606.000 .000 & 431.000 .000 & 78.900 .000 & 0,710 & 0,130 \\
\hline 8 & BCA & Konven. & 488.000 .000 & 312.000 .000 & 62.700 .000 & 0,639 & 0,128 \\
\hline 9 & BNI & Konven. & 371.000 .000 & 239.000 .000 & 47.000.000 & 0,646 & 0,127 \\
\hline 10 & CIMBNiaga & Konven. & 211.000 .000 & 144.000 .000 & 25.300 .000 & 0,680 & 0,120 \\
\hline \multicolumn{3}{|c|}{ Total \& Rata-rata } & 2.324 .000 .000 & 1.543 .000 .000 & 296.500 .000 & 0.664 & 0,126 \\
\hline
\end{tabular}

Catatan: total asset, kredit, dan ekuitas dalam nilai ribuan.

Tabel 3. Hasil estimasi fungsi biaya trans-logaritma

\begin{tabular}{|c|c|c|c|c|c|}
\hline \multirow{2}{*}{ Variabel independen } & \multicolumn{5}{|c|}{ Variabel dependen: Total Biaya (TC) } \\
\hline & 2009 & 2010 & 2011 & 2012 & 2013 \\
\hline Konstanta & 0.029 & -0.011 & $0.144^{* * *}$ & $0.166^{* *}$ & $-0.084^{\star * *}$ \\
\hline LnTA & -0.033 & $0.597 * * *$ & -0.018 & 0.201 & $1.668^{* * *}$ \\
\hline $1 / 2(\operatorname{LnTA})^{2}$ & 6.436 & 1.485 & $8.843^{* * *}$ & 5.290 & $-22.306^{* * *}$ \\
\hline $\operatorname{LnW}_{1}$ & -0.256 & -0.012 & -0.068 & -0.117 & $0.688^{* * *}$ \\
\hline $\mathrm{LnW}_{2}$ & $0.841^{* * *}$ & $0.471^{* * *}$ & $0.821^{* * *}$ & $0.497 * * *$ & $-0.453^{* * *}$ \\
\hline $\mathrm{LnW}_{3}$ & 0.500 & $0.584^{* * *}$ & $0.236 * *$ & 0.256 & 0.231 \\
\hline $\mathrm{LnW}_{1} \times \mathrm{LnW}_{1}$ & -1.383 & $0.481^{*}$ & 0.454 & $1.335^{* * *}$ & $-2.217^{* * *}$ \\
\hline $\mathrm{LnW}_{2} \times \mathrm{LnW}_{2}$ & 0.130 & -0.015 & $1.930 * * *$ & 0.613 & -0.004 \\
\hline $\mathrm{LnW}_{3} \times \mathrm{LnW}_{3}$ & -0.261 & 0.380 & $1.380^{* *}$ & 0.447 & $1.864^{* * *}$ \\
\hline $\mathrm{LnW}_{1} \times \mathrm{LnW}_{2}$ & 0.674 & 0.026 & $-1.311^{* *}$ & $-1.382^{* *}$ & $4.116^{* * *}$ \\
\hline $\mathrm{LnW}_{1} \times \mathrm{LnW}_{3}$ & 2.207 & -0.887 & 0.611 & $-1.407^{* *}$ & $0.450^{* *}$ \\
\hline $\mathrm{LnW}_{2} \times \mathrm{LnW}_{3}$ & -1.611 & 0.053 & $-3.246^{* * *}$ & 0.141 & $-4.078^{* * *}$ \\
\hline $\operatorname{LnTA} \times \operatorname{LnW}_{1}$ & $6.036 * *$ & 1.039 & 1.364 & 2.707 & $-14.782^{* * *}$ \\
\hline LnTA $x \mathrm{LnW}_{2}$ & $-3.495^{* * *}$ & -0.719 & $-5.411^{* * *}$ & $-4.172^{* * *}$ & $12.493^{* * *}$ \\
\hline $\operatorname{LnTA} \times \operatorname{LnW}_{3}$ & -1.059 & -0.143 & $4.493^{* * *}$ & 1.236 & 1.852 \\
\hline $\mathrm{N}$ & 30 & 40 & 40 & 40 & 40 \\
\hline $\mathrm{R}^{2}$ & 0.98 & 0.99 & 0.99 & 0.99 & 0.99 \\
\hline
\end{tabular}

Catatan: Estimasi ini berdasar pada persamaan (I). TC adalah total biaya. Persamaan (I) diestimasi menggunakan pooled least squares. TA adalah total asset. $\mathrm{W}_{1}, \mathrm{~W}_{2}$, dan $\mathrm{W}_{3}$ masing-masing merupakan biaya tenaga kerja, biaya kapiital, dan biaya pendanaan. Dalam tabel ini, peneliti hanya menampilkan koefisien dan level signifikansi untuk simplifikasi hasil. ${ }^{*},{ }^{* *}$, dan $* * *$ masing-masing mengindikasikan tingkat signifikansi pada level $10 \%, 5 \%$, dan $1 \%$. 
sional secara rata-rata $12,6 \%$, sedangkan bank syariah hanya $8,1 \%$. Dengan demikian, dari statistik deskriptif yang tersaji pada tabel 2, kita dapat menyimpulkan babwa bank konvensional memiliki pangsa pasar yang lebih luas daripada bank syariah. Bank konvensional juga lebih baik dalam hal aset, kredit, dan ekuitas.

\section{Indeks Lerner}

Persamaan (I) dijalankan untuk mendapatkan $5 \alpha$ and $\gamma$ untuk digunakan dalam penghitungan biaya marginal. Persamaan (I) tersebut dijalankan di setiap tahun karena tingkat kompetisi perbankan di tiap tahun dapat berbeda. Hasil regresi persamaan (I) tersebut ditunjukkan dalam tabel 3. Tiga input biaya berupa biaya tenaga kerja, biaya modal, dan biaya pendanaan terbukti berhubungan erat dengan total biaya yang dikeluarkan oleh perusahaan. Hal ini ditunjukkan dengan tingginya goodness-of-fit $\left(\mathrm{R}^{2}\right)$ pada setiap estimasi.
Langkah selanjutnya adalah penghitungan biaya marginal. Indeks Lerner kemudian dihitung menggunakan persamaan (III) setelah nilai biaya marginal didapatkan. Hasil penghitungan indeks Lerner ini ditunjukkan pada tabel 4. Seperti pada literatur terdahulu (Soedarmono et al., 2011), indeks Lerner dalam penelitian ini menunjukkan nilai ekstrim diluar rentang 0 dan 1 . Nilai maksimum indeks Lerner dari bank konvensional dan bank syariah masing-masing 1,2 dan 1,3. Rata-rata indeks Lerner bank syariah sebesar 0,44 , sedangkan dari bank konvensional didapatkan nilai 0,56 .

Tabel 5 menunjukkan hasil dari uji beda ratarata indeks Lerner dua bank di tiap tahun. Terkecuali di tahun 2013, bank konvensional memiliki daya saing yang lebih tinggi dibanding bank syariah. Daya saing bank syariah di Indonesia secara signifikan lebih rendah di tahun 2009, 2010, dan 2011, dengan significance level 5\% dan 1\%. Rendahnya daya saing bank syariah juga ditunjukkan

Tabel 4. Indeks Lerner

\begin{tabular}{lrrrrr}
\hline \multicolumn{7}{c}{ Panel A: Bank Syariah } \\
\hline Tahun & Jml. Obs. & Rata-rata & Std. Dev. & Minimum & Maksimum \\
2009 & 10 & 0.135 & 0.279 & -0.288 & 0.702 \\
2010 & 20 & 0.390 & 0.142 & 0.139 & 0.758 \\
2011 & 20 & 0.421 & 0.469 & -0.215 & 1.251 \\
2012 & 20 & 0.656 & 0.288 & -0.035 & 0.941 \\
2013 & 10 & 0.490 & 0.426 & -0.286 & 0.953 \\
\hline \multicolumn{7}{c}{ Panel B: Bank Konvensional } \\
\hline Tahun & Jml. Obs. & Rata-rata & Std. Dev. & Minimum & Maksimum \\
2009 & 15 & 0.427 & 0.322 & -0.124 & 0.949 \\
2010 & 20 & 0.580 & 0.185 & 0.325 & 1.001 \\
2011 & 20 & 0.803 & 0.249 & 0.278 & 1.332 \\
2012 & 20 & 0.741 & 0.256 & -0.007 & 1.175 \\
2013 & 17 & 0.156 & 0.526 & -0.763 & 0.835 \\
\hline \multicolumn{7}{c}{ Panel C: Semua tahun } \\
\hline Tipe bank & Rata-rata & Std. Dev. & Minimum & Maksimum \\
Bank syariah & Jml & 0.445 & 0.363 & -0.288 & 1.251 \\
Bank konvensional & 92 & 0.560 & 0.390 & -0.763 & 1.332 \\
Total & 172 & 0.507 & 0.381 & -0.763 & 1.332 \\
\hline \multicolumn{7}{c}{ Obs. }
\end{tabular}


dalam gabungan tahun. Secara umum, peneliti dapat menyimpulkan bahwa daya saing bank konvensional secara signifikan lebih baik dari bank syariah, dalam significance level $1 \%$ dan $5 \%$.

\section{Daya saing, utilisasi aset, dan risiko}

Pada bagian ini, peneliti akan menelaah lebih lanjut tentang apakah perbedaan indeks Lerner yang didapatkan pada uji beda rata-rata juga signifikan setelah mengontrol variabel-variabel lain. Untuk itu, peneliti mengestimasi persamaan (IV) menggunakan metode pooled least square. Hasil regresi ditunjukkan pada tabel 6. Variabel Syariah, atau variabel dummy yang bernilai 1 jika bank syariah, menunjukkan nilai negatif yang berarti daya saing bank syariah lebih rendah $13 \%$ daripada bank konvensional. Hasil ini tidak berubah dalam ketiga estimasi yang lain, saat mempertimbangkan dummy quarter dan robust standard error. Meskipun signifikansi Syariah berkurang pada estimasi (3) dan (4), namun variabel ini masih dapat dikatakan signifikan pada level $10 \%$.

Tabel 5. Uji beda rata-rata

\begin{tabular}{lccc}
\hline Tahun & Perbedaan rata-rata & t-statistik & p-value \\
\hline 2009 & -0.292 & -2.338 & 0.028 \\
2010 & -0.190 & -3.643 & 0.000 \\
2011 & -0.382 & -3.217 & 0.002 \\
2012 & -0.085 & -0.986 & 0.330 \\
2013 & 0.334 & 1.702 & 0.101 \\
Semua tahun & -0.115 & -1.992 & 0.048 \\
\hline
\end{tabular}

Tabel 6. Hasil regresi

\begin{tabular}{|c|c|c|c|c|}
\hline \multirow{2}{*}{ Variabel independen } & \multicolumn{4}{|c|}{ Variabel dependen: Daya saing (indeks Lerner) } \\
\hline & $(1)$ & $(2)$ & $(3)$ & $(4)$ \\
\hline \multirow[t]{2}{*}{ Syariah } & $-0.130^{* * *}$ & $-0.135^{* * *}$ & $-0.130 *$ & $-0.135^{*}$ \\
\hline & $(-4.34)$ & $(-4.46)$ & $(-2.07)$ & $(-1.97)$ \\
\hline \multirow[t]{2}{*}{ Utilisasi aset } & $-0.195^{* * *}$ & $-0.208^{* * *}$ & -0.195 & -0.208 \\
\hline & $(-3.06)$ & $(-3.22)$ & $(-0.99)$ & $(-0.99)$ \\
\hline \multirow[t]{2}{*}{ Risiko } & $-0.703^{* * *}$ & $-0.698^{* * *}$ & -0.703 & -0.698 \\
\hline & $(-3.42)$ & $(-3.29)$ & $(-1.70)$ & $(-1.50)$ \\
\hline \multirow[t]{2}{*}{ Konstanta } & $0.450 * * *$ & $0.408^{* * *}$ & $0.450 * * *$ & $0.408^{* *}$ \\
\hline & $(9.38)$ & $(7.10)$ & $(3.47)$ & $(2.98)$ \\
\hline Dummy kuartal & - & $\sqrt{ }$ & - & $\sqrt{ }$ \\
\hline Robust Std. Error by cluster & - & - & $\sqrt{ }$ & $\sqrt{ }$ \\
\hline Jumlah observasi & 200 & 200 & 200 & 200 \\
\hline $\mathrm{R}^{2}$ & 0.11 & 0.19 & 0.11 & 0.19 \\
\hline
\end{tabular}

Catatan: Hasil regresi ini berdasar pada estimasi dengan teknik PLS (Pooled Least Squares). Angka dalam kurung adalah t-statistik. $* * *, * *$, dan * masing-masing menunjukkan signifikansi pada level $10 \%, 5 \%$, dan $1 \%$. 
Mengenai kontrol variabel dalam penelitian ini, dalam estimasi (1) dan (2), utilisasi aset dan risiko memiliki pengaruh negatif terhadap daya saing bank. Hal ini berarti semakin tinggi utilisasi aset perbankan atau semakin rendah risiko perbankan berhubungan dengan rendahnya daya saing bank.

\section{KESIMPULAN DAN SARAN}

Penelitian ini menginvestigasi daya saing bank syariah dan bank konvensional di Indonesia untuk menjawab pertanyaan apakah bank syariah memiliki daya saing yang lebih baik di negara yang memiliki religiusitas tinggi seperti Indonesia. Peneliti menggunakan indeks Lerner untuk mengukur daya saing bank. Hasil yang peneliti dapatkan dalam penelitian ini menunjukkan bahwa daya saing bank syariah secara signifikan lebih rendah dari bank konvensional. Penelitian ini juga menunjukkan bahwa bank konvesional sangat superior dalam hal utilisasi aset mereka. Risiko bank konvensional yang ditunjukkan dari rasio kapital juga lebih rendah daripada bank syariah. Hasil penelitian ini mengindikasikan bahwa religiusitas sebuah negara tidak menjamin bahwa bank syariah akan memiliki posisi yang lebih baik di masyarakat dan pasar perbankan.

Penelitian ini memiliki kontribusi kebijakan yaitu bahwa Direktorat Perbankan Syariah di Bank Indonesia belum bekerja secara efektif. Bank Indonesia perlu memikirkan cara yang lain untuk mengembangkan daya saing bank syariah dalam meningkatkan stabilitas keuangan negara. Keseimbangan antara bank syariah dan bank konvensional sangat penting untuk stabilitas keuangan.

Salah satu batasan penelitian ini adalah tentang pemilihan sampel. Akan lebih baik jika sebuah penelitian dapat membandingkan dua sampel yang memiliki karakteristik yang cukup sama. Membandingkan bank syariah dengan pangsa pasar $6 \%$ dengan bank konvensional yang menguasai $80 \%$ pasar perbankan dirasa kurang fair. Dengan demi- kian, penelitian ini mendorong penelitian selanjutnya untuk mempelajari daya saing perbankan menggunakan karakteristik bank yang sama.

\section{DAFTAR PUSTAKA}

Beck, T., Demirgüç-Kunt, A., Merrouche, O. 2013. Islamic vs. Conventional banking: Business model, efficiency and stability. Journal of Banking $\mathcal{E}$ Finance 37(2): 433-447

De Guevara, J.F., Maudos, J., Perez, F. 2005. Market power in european banking sectors. Journal of Financial Services Research 27(2): 109-137

Ernst and Young. 2014. EY World Islamic banking competitiveness report 2014-15.

Falikhatun F., Assegaf Y. U., Hasim, H. 2016. Menelisik makna pembiayaan qardhul hasan dan implementasinya pada perbankan di Indonesia. Jurnal Keuangan dan Perbankan 20(1): 94-103

Fu, X., Lin, Y., Molyneux, P. 2014. Bank competition and financial stability in asia pacific. Journal of Banking \& Finance 3864-77

Gheeraert, L. Does Islamic finance spur banking sector development? Journal of Economic Behavior and Organization 103: S4-S20

Hamza, H., Katchouli, S. 2014. Competitive conditions and market power of islamic and conventional commercial banks. Journal of Islamic Accounting and Business Research 5(1): 29-46

Leon, F. 2015. Does bank competition alleviate credit constraints in developing countries? Journal of Banking $\mathcal{E}$ Finance 57: 130-142

Love, I., Martinez-Peria, M. S. 2015. How bank competition affects firms' access to finance. World Bank Economic Review 29(3): 413-448

Mulyaningsih, T., Daly, A., Miranti, R. 2015. Foreign participation and banking competition: Evidence from Indonesian banking industry. Journal of Financial Stability 19: 70-82

Soedarmono, W., Machrouh, F., Tarazi, A. 2011. Bank market power, economic growth and financial stability: Evidence from asian banks. Journal of Asian Economics 22(6): 460-470 


\section{Daya Saing bank Syariah di Sebuah Negara Religius: Temuan Empirik dari Indonesia}

Tastaftiyan Risfandy, Putri Permatasari Husa, Andi Asrihapsari

Turk-Ariss, R. 2010. Competitive conditions in islamic and conventional banking: A global perspective. Review of Financial Economics 19(3): 101-108

Tan, Y. 2015. The impacts of risk and competition on bank profitability in China. Journal of International Financial Markets, Institutions and Money 40: 85-100
Weill, L. 2011. Do islamic banks have greater market power? Comparative Economic Studies 53(2): 291306

World Bank. 2014. World Bank Global Financial Development Report: Financial Inclusion, Vol. 133, pp. $372-378$ 